\title{
Penguatan Peran Negara dalam Implementasi Demokrasi Lokal di Indonesia
}

\author{
Asrinaldi A
}

This article aims to elaborate the role of state on implementing democracy at the local level. State, in which, often representing by government, facing dilema. In one hand, role of state is needed to keep democratization on the right track. It means that state must guarantee its citizen will not behave anarchism. Other hand, if state's role is too far, it can also threat its citizen's freedom. Therefore, this article want to show what aspects of political elite consideration in making strong state and have role in local autonomy as a part of local democracy in Indonesia through implementing Law No. 32/ 2004.

Kata Kunci: Kearifan, Liberalisasi, Pendidikan, Ideologi, Nasional

Implementasi otonomi daerah di Indone Isia berkaitan erat dengan kewujudan mempertahankan Negara Kesatuan Republik Indonesia (NKRI).Tidak ada sebarang keinginan yang bisa diminta daerah kepada pusat khususnya dalam menyelenggarakan fungsi pemerintahan daerah, kecuali dalam kerangka memperkuat kedudukan NKRl di seluruh wilayah Indonesia. Bagi pemerintah pusat bukanlah hal yang mudah untuk mempertahankan teritorialnya di tengah menguatnya kekuatan supranasional, integrasi sistem ekonomi internasional, dan globalisasi. Ini bisa jadi menjadi tantangan serius bagi kewujudan negara bangsa di dunia, termasuk indonesia (King \& Kendall 2004:5). Pemerintah pusat menyadari betul upaya ini harus didukung oleh kekuatan politik termasuk lembaga-lembaga negara (state apparatus) seperti birokrasi dan militer. Maknanya, kedaulatan teritori NKRI mesti mampu dikendalikan pusat dengan otoritas penuh yang dapat menjangkau seluruh daerah di Indonesia. Melalui penguasaan struktur kekuasaan politik dan finansial pusat menjadi kuat atas daerah. Inilah satu antara langkah yang dilakukan Pemerintahan Orde Baru bagi menguatkan kekuasaannya pada mula kepimpinan Presiden Soeharto (MacAndrews 1986: 67). ${ }^{\top}$

1. Pada masa kepemimpinan Presiden Soekarno, implementasi demokrasi terpimpin (1959-1965) sengaja dirancang untuk mengekalkan kekuasaan pemerintah pusat atas daerah. Terjadinya pemberontakan PRRII Permesta tahun 1958 di Sumatera dan Sulawesi adalah bukti penantangan terhadap kuatnya kekuasaan Presiden Soekarno atas rakyat daerah. Oleh Presiden Soekarno pemberontakan ini dihadapi dengan kekuatan militer. Pengunaan militer yang berlebihan adalah bukti kuatnya Negara. Keberhasilannya menghancurkan pemberontak di seluruh 
Melalui legitimasi dan otoritas politik penuh yang dimilikinya, tak jarang pemerintah pusat mengartikan gejala-gejala politik yang muncul dalam kehidupan berbangsa dan bemegara dengan tafsirannya sendiri. Konsekuensinya jelas kepada kebijakan dan tindakan yang mesti dilakukannya. Adakalanya pusat menyikapi kondisi politik yang berlaku dalam kehidupan masyarakat secara otoritarian, karena dianggap dapat membahayakan kelang-sungan NKRI. Misalnya, menyangkut kewujudan nasionalisme yang mesti ditanamkan dalam jiwa dan semangat Rakyat Indonesia yang multi etnis, multi agama, dan beragam kebudayaan sebagai bagian dari strategi politiknya dalam mengendalikan kemajemukan rakyat Indonesia.

Nasionalisme juga diciptakan untuk mewujudkan pertumbuhan ekonomi, stabilitas politik, dan pemerataan bagi kesejahteraan bersama. Kecenderungan ini yang menjadi bagian kebijakan politik Pemerintah Orde Baru yang dikenal dengan trilogi pembangunan (Lihat Liddle 1999: 52). Nasionalisme Indonesia dibungkus ke dalam ideologi Pancasila dan semboyan Bhinneka Tunggal ka. $^{2}$ Atas nama "kebersamaan dengan indonesia" inilah, maka pusat berupaya memahami apa yang diperlukan dan yang baik bagi Rakyat Indonesia. Gantinya rakyat dituntut pula untuk berkhidmat pada pemerintah pusat, termasuk tuntutan melaksanakan semangat kebersamaan dalam keindonesian yang lazim disebut persatuan Indonesia (McVey 2003:21). Pemerintah pusat atas nama Negara Indonesia berterusan menanamkan semangat kebersamaan ini demi keutuhan Negara Kesatuan Republik Indonesia yang hingga saat ini terus mencari bentuk yang sesuai dengan keberagaman bangsa.Indonesia.
Negara kesatuan (unitary state) adalah merupakan agenda utama dalam proses pembentukan Negara Indonesia yang ada di pusat. Ini terbukti bahwa dalam amandemen konstitusi Republik Indonesia (UUD 1945) yang bisa diwujudkan setelah reformasi politik tahun 1998. Amandemen terhadap UUD 1945 ini melarang mengubah bentuk negara kesatuan ke dalam bentuk lain. ${ }^{3}$ Asumsi elitee politik di Jakarta adalah bahwa negara kesatuan adalah bentuk akhir dan yang paling sesuai dengan realitas rakyat Indonesia yang pluralistik. ${ }^{4}$ Oleh kerana itu, kenyataan ini harus disadari oleh semua elite yang berkuasa termasuk rakyatnya bahwa bentuk NKRI adaiah satu cara yang sesuai dan hal yang "final" dalam proses mewujudkan "Indonesia."

wilayah indonesia yang penuh gejolak memunculkan gagasannya untuk mengekalkan pelaksanaan demokrasi terpimpin (Cribb 1999: 31-32). Begitu juga dengan Pemerintahan Orde Baru, yang mengutamakan jargon stabilitas politik, pembangunan ekonomi dan pemerataan mengekalkan kekuatannya negara atas rakyatnya.

2. Bhineka Tunggal lka berarti walaupun berbeda-beda (etnis, agama, daerah dan lainlain) namun tetap satu dalam lingkup Indonesia.

3. Ada empat perkara yang tidak bisa diubah dalam amandemen konstitusi Republik Indonesia yaitu: (i) Pembukaan UUD 1945; (ii) Bentuk negara kesatuan; (iii) Sistem pemerintahan presidensiil; dan (iv) Pasal tentang kehidupan beragama.

4. Negara Indonesia pērnah berbentuk Republik Indonesia Serikat (RIS) tahun 19491950. Pembentukan ini adalah dampak dari agresi Belanda yang melahirkan perjanjian Linggar Djati dan Renville. Namun bentuk Negara ini tidak bertahan lama dan pada masa berikutnya Indonesia kembali ke bentuk kesatuan sebagai strateginya untuk mematahkan politik kekuasaan Belanda (Lihat Agung 1983; Kahin 2005:150-160). 
Dalam realitasnya, elite politik di Jakarta bertindak sebagai negara dan menafsirkan kepentingan-kepentingan negara. Namun malangnya, tindakan dan tafsiran kepentingan atas nama negara ini seringkali berisikan pula tindakan dan kepentingan elite dan kelompoknya terutama untuk mengekalkan kekuasaan politik yang ada di tangan mereka. Kecenderungan ini menimbulkan permasalahan apakah memang "Negara Indonesia" mempunyai kepentingan terhadap keharusan wujud negara kesatuan dan tidak bisa dalam bentuk lain? Apakah wujud dalam bentuk lain seperti federalisme, yang apabila dikehendaki rakyat di daerah mesti ditolak? Apakah "negara" mesti berkuasa meniadakan keinginan tersebut? Bagaimana pula negara harus bersikap dengan demokrasi yang muncul di tingkat lokal dimana menghendaki terciptanya kesejahteraan, keadilan dan pengakuan terhadap hak-hak politik mereka? Bagi menjawab perkara di atas, maka tulisan ini akan coba membincangkan tentang hubungan negara dan rakyat lebih mendalam terkait dengan pelaksanaan demokrasi di tingkat lokal.

\section{Pembentukan Negara Kuat dalam Perspektif Kekuasaan Pusat Terhadap Daerah Dampaknya bagi Demokrasi di Tingkat Lokal}

Sesuai dengan masalah yang disampaikan di atas, bisa dimengerti bahwa negara ialah organisasi legal rasional yang dilembagakan atas kesepakatan individuindividu melalui ikatan sosial (social contract) guna mencegah anarki dan menjamin terciptanya tertib sosial dalam masyarakat. Namun, harus pula diakui karana negara diselenggarakan oleh pemerintah yang merupakan kelas penguasa (the rulling class) tentunya kepentingan kelompok penguasa ini berada pula dalam negara sehingga adakalanya bertentangan dengan kepentingan publik.

Kenyataan yang bisa dipahami bahwa selama kepemimpinan dua regim yang berkuasa di Indonesia yaitu Orde Lama dan Orde Baru, tiap-tiapnya secara jelas memanfaatkan kekuasaan negara yang ada. Dengan berbagai alasan utamanya demi keutuhan Negara Kesatuan Republik Indonesia, pemerintah berkuasa memanipulasi kepentingan rakyat yang ada pada negara. Hakikat bernegara dalam konteks ke-indonesia-an diartikan sendiri oleh elite politik tanpa melibatkan rakyat. Elite politik khususnya mereka yang berada di keliling kekuasaan Presiden Soekamo dan Presiden Soeharto ikut menentukan rancangan negara Indonesia. Bagi mewujudkan kehendak penguasa (baik Presiden Soekarno mahupun Presiden Soeharto), kebijakan politik yang dibuat mesti diberlakukan secara represif dengan alasan menjaga stabilitas politik dan keamanan bagi rakyat. Elite politik berangapan bahwa ancaman terhadap stabilitas politik bisa menggangu proses pembangunan ekonomi untuk rakyat.

Miliband (1969: 49) menerangkan tentang negara sebagai sesuatu yang tidak berwujud. Namun, menurutnya negara merupakan sejumlah lembaga khusus yang merupakan bagian-bagian negara yang berwujud secara realitas di mana masingmasingnya saling berinteraksi yang disebut dengan sistem negara. Satu diantara bagian tersebut ialah pemerintah. Oleh itu, apabila berbicara tentang kekuasaan negara, maka sesungguhnya berbicara tentang kekuasaan pemerintah. "Thus, if it is believed that the government is in fact the state, it may also be believed that the assumption of governmental power equivalent to the acquisition of state power." Kekuasaan negara yang sesungguhnya dilegitimasi oleh rakyat dalam praktiknya akan berpindah ke tangan 
pemerintah. Kekuasaan negara pada akhirnya menjadi kekuasaan sekelompok elite politik yang berkuasa (the rulling class) dan bahkan elite politik ini cenderung menjalankannya secara oligarki. Bahkan pada masa sesudah reformasi politik pun kecenderungan oligarki kekuasaan semakin menampakan rwujudnya. Ini bisa dibuktikan di mana yang menentukan tujuan Negara Kesatuan Republik Indonesia ada pada sekelompok elite politik yang berasal dari partai yang berkuasa (the rulling party). ${ }^{5}$

Indonesia sebagai negara bangsa modern (modern nation state) ada sejak kemerdekaan pada 17 Agustus 1945. Dalam pembukaan (preamble) UUD 1945Alinea ke IV ditegaskan bahwa tujuan negara Indonesia itu ialah sebagai berikut. "Kemudian daripada itu untuk membentuk suatu Negara Indonesia yang melindungi segenap Bangsa Indonesia, memajukan kesejahteraan umum, mencerdaskan kehidupan bangsa, ikut serta menciptakan perdamaian abadidan keadilan sosial [...]." Sesuai dengan teori negara yang diurai di atas, kewujudan negara Indonesia merupakan suatu proses kontrak sosial seluruh Bangsa Indonesia yang dituangkan dalam Pembukaan UUD 1945. Oleh itu, dalam perubahan UUD 1945, pembukaan tidak bisa diubah. Sebab mengubah pembukaan UUD 1945 berarti mengubah kontrak sosial yang dibuat oleh pendiri negara ini.

Justeru yang penting untuk dilakukan ialah mengekalkan negara Indonesia menjadi negara yang kuat, sehingga tujuan apapun yang dicita-citakan seluruh bangsa Indonesia bisa dicapai. Apabila dilihat dari kenyataan sejarah yang berlaku di dunia, kondisi negara kuat ini terkait pula dengan penerapan bentuk negara. Pilihan elite politik terhadap bentuk federal atau konfederasi bisa jadi akan menghancurkan bangsa. Oleh itu, pertimbangan keberagaman etnis, ras dan agama menjadi salah satu aspek yang menjadi pertimbangan. Bisa dilihat beberapa-kasus khususnya di Eropa yang mem-perlihatkan bahwa pertikaian etnis, ras dan bahkan agama ini bisa menghancurkan negara yang mulanya kuat (Dieckhoff 2003: 273). ${ }^{6}$

Pembentukan negara kuat ini bermula dari adanya pengakuan kedaulatan dan otoritas dari segenap bangsa yang berada di suatu wilayah. Kekuasaan yang dilembagakan itu mengikat dan bahkan cenderung memaksa agar rakyat bertindak sesuai kehendak negara. Negara bisa memanfaatkan alat-alat kekuasaannya seperti militer, birokrasi, dan regim, supaya bisa memaksakan kehendaknya. Namun, sebagaimana yang disampaikan Miliband (1969) kekuasaan negara sesungguhnya tidaklah berwujud. Karana itu, wujud kekuasaan negara ialah implementasi kekuasaan pemerintah itu. Jadi kebijakan apa yang dibuat pemerintah

5. Kecenderungan ini mulai menguat ketika reformasi politik berlangsung. Tujuan Negara adakalanya diputuskan pada pertemuan informal elite politik dari partai yang berkuasa (i.e. PDIP, P.Golkar, PKB, PPP dan lain sebagainya). Praktik politik formal di parlemen hanya sekadar untuk legitimasi polisi yang dibuat. Bagi anggota partai yang bertentangan dengan garis kesepakatan partai, maka akan diberlakukan recall oleh Partai yang bersangkutan. Inilah kecenderungan politik baru dalam transisi demokrasi di Indonesia. Jelas ini berbeda dengan proses politik yang ada pada masa Presiden Soekarno maupun Soeharto. Keduaduanya hanya memanfaatkan orang dalam lingkaran kekuasaan (the inner cycle) sebagai pertimbangan dalam membuat kebijakan politik (Jackson 1978; Gaffar 1999).

6. Setelah perang dingin, peta politik dunia berubah. Kekuatan demokrasi berhasil mengubah ideologi komunis menjadi demokrasi liberal. Khususnya di Eropa Timur, transisi demokrasi yang berlangsung tidak selaras dengan apa yang semestinya diharapkan. Pada akhimya, transisi demokrasi ini berakhir dengan kekacauan dan perang saudara. Misalnya di negara bekas Yugoslavia, Slovakja, Romania, dan Albania. 
adalah gambaran kekuasaan negara. Namun siapa yang bisa menjamin bahwa kekuasaan negara yang diambil dan diperankan oleh the rulling class adalah untuk kepentingan bersama dan atas nama kebersamaan.Kenyataannya banyak pemerintah yang berkuasa memanfaatkan keadaan ini demi status quo kekuasaannya.

Di negara yang sedang membangun persoalan pembentukan negara kuat menjadi agenda utama elite politik. Pembentukan negara kuat ini sesungguhnya juga bagian dari pembangunan negara di mana ada upaya penciptaan lembaga-lembaga pemerintahan baru dan penguatan lembaga-lembaga yang telah ada. Sebab bisa jadi, tanpa negara kuat pembangunan tidak bisa dilangsungkan. Apabila merujuk pada apa yang dikatakan Fukuyama (2005: xvii) "pembangurian negara merupakan salah satu persoalan paling penting bagi komunitas dunia karena negara-negara lemah atau gagal adalah sumber dari banyak persoalan dunia yang paling serius, mulai dari kemiskinan, AIDS, obat bius, hingga terorisme."

\section{Pelaksanaan}

pembangunan membutuhkan kerangka dasar negara yang kuat termasuk ideologi penguasa yang mesti disosialisasikan kepada rakyatnya. Selain itu, mobilisasi sumber daya yang ada termasuk sokongan rakyat merupakan kemestian. Bagi elite politik untuk mencapai perkara yang demikian, pilihannya hanyalah membentuk regim otoritarian atau totalitarian (Linz \& Stephan 1996: 38-42). Kecendenungan ini pun berlaku di Indonesia. Pembentukan negara kuat menjadi alasan utama elite politik untuk melaksanakan pembangunan. Walaupun dalam praktiknya ini tidaksepenuhnya berlaku.? Elite politik justru berupaya mengekalkan kekuasaan yang ada ditangannya.

Pembentukan negara kuat (strong state) bertujuan untuk memudahkan mobilisasi sumber daya guna mewujudkan tidak hanya tujuan negara tapi juga tujuan kekuasaan elite yang memerintah. Negara kuat bisa dilihat daripada otonomi politik yang diperolehi oleh rakyatnya. Semakin tidak otonom rakyat dalam menentukan pilihan-pilihan politik, adalah bukti semakin kuat negara tersebut. Dampak semakin kuatnya kekuasaan negara ialah ancaman terhadap pelaksanaan demokrasi. Ryaas Rasyid (1994: 16) menyebutkan "[S]tate formation aims at increasing the strenght and autonomy of the state. Strenght state is also measured by the level of authonomy it has inforcing its society."

Apabila melihat sejarah yang terjadi di Indonesia tahun 1950-an, penerapan sistem demokrasi liberal dengan mengutamakan partisipasi individu warga negara dalam politik, kedudukan negara (atau pemerintah) menjadi lemah. Ini terbukti dengan jatuhbangunnya kabinet sehingga tidak mampu mewujudkan agenda pembangunan bagi rakyatnya. Yang selalu menjadi perkara dalam bernegara selalu berkaitan erat dengan kompetisi politik baik elite maupun

7. Pada masa Orde Lama Presiden Soekarno berupaya mengimplementasikan demokrasi terpimpin 1959-1965 guna menjaga stabilitas politik yang mengancam negara yang diambang kehancuran. Ini disebabkan oleh perseteruan partai di Dewan Konstituante mengancam keutuhan Negara Indonesia. Elite lebih disibukkan oleh urusan politik berbanding dengan pembangunan ekonomi (lihat Nasution 1995). Namun seiring berjalannya waktu tujuan menjaga keutuhan Negara Indonesia berubah menjadi penguatan kekuasaan Presiden Soekarno. Begitu juga pada masa Presiden Soeharto yang belajar dari regim Orde Lama yang sibuk dengan masalah politik, menguatkan kekuasaannya dengan alasan pembangunan ekonomi dan menjauhkan rakyat dari politik (depolitisasi massa). Bagi pembangunan ekonomi, stabilitas politik harus diciptakan apapun caranya. Impaknya regim mesti dijalankan secara otoritarian. 
partai politik. Lama-kelamaan perseteruan ini mengarah pada konflik politik kedaerahan yaitu antara Jawa atau luar Jawa. Puncak perseteruan elite politik yang mengangkat isu kedaerahan ini, adalah ketika Mohammad Hatta sebagai wakil luar Jawa mundur darijabatan wakil presiden. Akhimya ancaman terhadap disintegrasi bangsa menguat. Pemberontakan terhadap pemerintah pusat terjadi di banyak daerah (Lihat Legge 1961; Feith 1970; Kahin 2005). Jika dipahami bahwa gejala ini merupakan kenyataan, lemahnya negara dan kuatnya rakyat dalam sistem politik yang dibangun.

Di Indonesia kecenderungan pembentukan negara kuat ini menjadi agenda politik yang dirancang oleh elite yang berkuasa dari suatu kelompok atau partai politik yang ada. Tujuannya adalah agar negara, tentunya melalui pemerintah, memiliki kemampuan untuk bertindak berdasarkan kehendak pemerintah untuk mencapai kewujudan agenda politik, 'ekonomi dan sosial. Melalui kemampuan elite politik yang menguasai negara, maka lembaga-lembaga negara berkenaan mengarahkan rakyat guna berbuat sesuai dengan keinginan the rulling class. Trauma pada politik masa lalu yang memunculkan instabilitas politik, elite yang berkuasa berupaya mengendalikan politik rakyat dengan cara membentuk negara kuat termasuk dalam berotonomi.

Hubungan pemerintah pusat dan pemerintah daerah pun dirancang sedemikian rupa guna membuat daerah tidak leluasa bertindak secara politik apalagi menentang pusat sebagaimana yang pernah terjadi. Jelas, yang dihendaki ialah adanya perkhidmatan daerah kepada Jakarta. Tidak hanya dilakukan pada masa regim Orde Lama tapi juga Orde Baru. Ini bisa dilihat dari komentar Malley (1999: 75) berikut ini.
The incoming government's priorities ran in the opposite direction: toward establishing central control over a divided and politicized military and bureacracy, including steps further to centralize relations between Jakarta and the regions. Parallel policies to depoliticize society and limit political competition further reduced the ability of regional actors to mobilize support for local interests.

Apabila regim Orde Lama melakukan tindakan represif dengan memerangi elite dan masyarakat daerah yang terlibat menentang kekuasaan pusat (Legge 1961; MacAndrews 1986), maka regim Orde Baru mengambil peranan lain. Paling tidak ada 3 strategi yang dilakukan regim Orde Baru untuk mengendalikan kekuasaan politik di daerah. Pertama, menempatkan komandan militer untuk duduk di kekuasaan pemerintahan sipil (di provinsi, kota dan kabupaten) sebagai gubernur, walikota ataupun bupati. Kedua, merancang aturan perundangundangan yang berkait dengan hubungan pusat dan daerah di mana peran pusat dominan mengendalikan daerah, dan ketiga, menempatkan militer sebagai komando teritorial penuh untuk mengurangi persaingan politik dan pemerintahan di daerah (Malley 1999: 75-77). ${ }^{8}$ Dengan strategi ini, pemerintah berkuasa pada waktu

8. Strategi ini berhasil "melemahkan" daerah sehingga dengan mudah dikendalikan pusat. Dengan melibatkan militer dalam politik daerah, elite sipil menjadi tersisihkan terutama dalam pemilihan kepala daerah yang mesti mendapat dukungan dan restu pusat (Presiden Soeharto). Paling tidak sebelum kejatuhan Presiden Soeharto, upaya ini berhasil menguatkan negara sehingga agenda negara (baca pemerintah) bisa dilaksanakan di daerah. Bandingkan dengan penjelasan Ryaas Rasyid 1994. 
itu berhasil membentuk negara kuat sehingga tujuan kekuasaannya tercapai.

Perkara lain yang juga menarik dan bisa dianggap sebagai strategi di bidang ekonomi adalah dengan membuat ketergantungan daerah kepada pusat khususnya dalam pembiayaan aktifitas pemerintahan di daerah. Pada masa kedua regim berkuasa, keberhasilan membuat daerah bergantung pada pusat berakibat pada ketidakmampuan daerah untuk mandiri dan bahkan bersikap kritis kepada pusat. Kecuali pada masa Orde Lama di mana puncak perseteruan ekonomi dan politik antara pusat dan daerah ini melahirkan pemberontakan (Lihat Kahin 2005). Sebenarnya pada masa Orde Baru pun muncul pemberontakan bersenjata yang menentang ketidakadilan yang dibuat oleh pemerintah pusat ini. Seperti munculnya gerakan menuntut kemerdekaan diAceh dan Papua. Walaupun, diperangi dengan kekuatan bersenjata, namun gerakan ini terus menguat di dalam kehidupan rakyat di tingkat lokal. Hingga Orde Reformasi pun masalah ini terus muncul dan harus diselesaikan oleh pemerintah pusat dengan menggunakan strategi dialogis yang melahirkan perundingan-perundingan. Pemberlakuan otonomi khusus bagi Aceh dan Papua adalah pilihan politik yang harus diambil guna mempertahankan NKRI.

Pada aspek ekonomi terjadi pula upaya melemahkan kekuaan rakya daerah. Bisa dibayangkan, bahwa ketergantungan daerah pada pemerintah pusat dari segi keuangan guna pembiayaan aktivitas pemerintahan dan pembangunan mencapai 80 hingga 90 peratus pada masa Orde Lama (Mac-Andrew 1986:11). Begitu pula pada masa Orde Baru di mana ketergantungan daerah kepada pusat dalam masalah kewangan juga mencapai 90 peratus (Ryass Rasyid 1994).
Bentukan negara kuat tentunya merupakan pilihan elite untuk mewujudkan agenda negara yang lebih besar. Untuk kasus Indonesia, negara kuat tetap menjadi pilihan guna menciptakan cita-cita Negara Kesatuan Republik Indonesia yang ada di dalam konstitusi negara ini. Oleh itu, pemerintah pusat berupaya menanamkan pemahaman ini pada seluruh bangsa Indonesia yang pluralistik untuk bernaung dalam bentukan negara kesatuan (unitary state).

\section{Negara Lemah dan Ancaman Terhadap Integrasi Nasional dalam Pelaksanaan Otonomi Daerah}

Kewujudan negara yang lemah bisa dilihat pada praktik penyelenggaraan otonomi daerah berdasarkan UU No. 22 tahun 1999. Sebenarnya, masa implementasi UU No. 22 tahun 1999 masih dalam masa transisi dan konsolidasi demokrasi. Dampaknya negara menjadi berhati-hati untuk campur tangan proses politik dan pemerintahan di daerah. Namun, tidak terlibatnya negara daiam proses tersebut membawa pengaruh pula pada proses demokrasi yang berlangsung. Paling tidak ini dapat dilihat dari banyaknya kasus yang berlangsung di daerah selama periode transisi ke demokrasi tahun 19982003. Reformasi politik yang berdampak langsung pada perubahan atmosfir politik dan perundang-undangan, membawa pengaruh besar bagi kehidupan rakyat yang lebih demokratis.

Apabila dilihat dari kenyataan ini, dapatlah dipahami bahwa perubahan yang sedang dilakukan oleh pemerintah saat ini adalah sebagai langkah strategis bagi mewujudkan demokrasi dalam kehidupan rakyat. Pada dasarnya, demokrasi juga harus ada dalam kehidupan rakyat di tingkat lokal. Bagi pemerintah pusat, cara yang paling sesuai menghidupkan demokrasi di 
tingkat lokal ini ialah dengan mempraktikkan desentralisasi (Smith 1985:19). Walaupun demikian, ketika strategi ini dilaksanakan, pemerintah pusat juga menghadapi dilema. Dilema itu berkaitan dengan munculnya berbagai pemahaman dari daerah tentang bagaimana pelaksanaan demokrasi di tingkat lokal. Perbedaan pemahaman tentang demokrasi ini justru mengekalkan berbagai macam kekuasaan daerah yang bertentangan dengan kedaulatan pusat, kekuasaan elite daerah atas rakyatnya, dan bahkan kekuasaan daerah atas daerah lain yang justeru menimbulkan pertikaian antara rakyat dengan rakyat. Kasus kerusuhan etnis di Kalimantan antara suku Dayak dan Madura atau kerusuhan yang berlatar belakang agama di Maluku dan Poso adalah bukti yang tidak bisa dinafikan dalam proses berdemokrasi di tingkat lokal (Lihat Davidson 2005:170-173). Namun, karena ini sudah menjadi keniscayaan bagi reformasi yang sedang berlangsung, maka pemerintah pusat harus mewujudkan kondisi demokrasi ini.

Pemerintah pusat sebenarnya bisa mengandaikan, apabila demokrasi tidak dikawal khususnya di tingkat lokal, maka yang muncul ialah kekacauan yang dapat mengancam persatuan dan kesatuan bangsa. Apalagi dalam proses demokrasi yang baru berlangsung tersebut muncul pula persoalan yang berhubungan dengan perebutan kekuasaan (power building) di kalangan elite politik baik di panggung politik nasional mahupun di pentas daerah (Kleden 2003: 162). Kecenderungan ini bisa pula berpengaruh pada perilaku politik rakyat di daerah.

Oleh itu, bagi mengelakkan persaingan kekuasaan di kalangan elite ataupun kelompok-kelompok politik yang ada, maka pemerintah mendesak proses transisi ke arah demokrasi itu supaya berjalan dengan damai- baik di tingkat nasional maupun lokal. Perubahan signifikan yang dilakukan pemerintah pusat dalam berdemokrasi di tingkat lokal ialah memberikan otonomi daerah yang seluas-luasnya kepada daerah. Pemerintah pusat berkeyakinan pelaksanaan desentralisasi (politik dan keuangan) akan memudahkan pelaksanaan demokrasi di tingkat lokal. Rondinelli \& Cheema (1983:1516) menjelaskan beberapa keuntungan pemberian desentralisasi ini terutama dalam aspék hubungan pusat dan daerah. Antaranya ialah mengatasi masalah kendali pusat yang berlebihan atas daerah yang dapat memunculkan ketidaksukaan rakyat daerah kepada pusat, menambah sensitivitas pusat terhadap masalah-masalah di daerah, memberi tempat bagi representasi berbagai kelompok politik, agama, etnis, serta mampu meningkatkan stabilitas politik dan kesatuan nasional. Di balik itu semua, otonomi daerah juga menjadi salah satu wujud kebebasan bagi daerah untuk terlibat dalam merancang aktivitas politik dan pemerintahan di tingkat lokal guna menguatkan kekuasaan pemerintah pusat secara nasional (Smith 1985:19-20).

Sejak pelaksanaan UU No. 22 tahun 1999 pada Januari 2001, kehadirannya memang disambut dengan penuh gembira oleh elite apalagi rakyat di daerah. Bagi rakyat daerah kehadiran UU No. 22 tahun 1999 ini memperkuat kembali hak-hak politiknya dalam penyelenggaraan pemerintahan. Selain adanya pengakuan politik terhadap eksistensi mereka, UU ini juga menjanjikan pembangunan yang lebih pesat untuk daerah. Dampaknya ialah UU ini melahirkan persaingan positif antara daerah dalam mengisi program-program pemerintahan, pembangunan serta pelayanan publik yang lebih baik. Ini bisa dilihat pada tahun pertama pelaksanaan UU ini di mana pemerintah daerah berupaya 
Topik: Globalisasi dan Liberalisasi dalam Bidang Pendidikan

menyusun perencanaan strategis guna mewujudkan tujuannya. Tetapi kemudian, persaingan dalam pelaksanaan otonomi daerah mengalami pergeseran ke arah kerusakan serta menimbulkan berbagaibagai masalah pula. Antaranya ialah munculnya isu putera asli daerah untuk menduduki jabatan-jabatan publik di daerah masing-masing tanpa memberi kesempatan bagi rakyat pendatang untuk menduduki jabatan di daerah itu. Ini menunjukkan bahwa UU No. 22 tahun 1999 ini telah mewujudkan semangat kedaerahan yang lebih menebal sehingga bisa mengancam kesatuan bangsa Indonesia. Daerah-daerah banyak menuntut berpisah dengan kabupaten induk demi untuk membuat kabupaten baru. Tidak bisa dinafikan percambahan kabupaten baru ini semakin ramai sejak UU ini dilaksanakan.

Kelemahan lain UU ini ialah birokrasi publik di daerah menjadi otokratik seperti mana birokrasi pemerintah.di tingkat pusat. Gambaran ini dapat dilihat dalam kenaikan pangkat seseorang pegawai yang lebih menonjolkan unsur kronisme dan kekeluargaan (spoil system), bukannya pada asas keahlian (merit system). Tidak terelakan pula masalah perselisihan batas wilayah kabupaten/kota dengan daerah otonomi lain yang bertetangga menambah daftar perkara impak pelaksanaan otonomi yang seluas-luasnya ini (Wasistiono 2005:178-179). Di sebahagian besar kabupaten/kota yang menjadi titik tolak pelaksanaan otonomi daerah muncul pula masalah dalam meningkatkan pendapatan asli daerah guna membiayai program pemerintah daerah yang kemudiannya menimbulkan berbagai macam biaya yang dipungut kepada rakyat. ${ }^{9}$ Jelas semua dampak negatif ini tidak bersesuaian dengan apa yang sesungguhnya diharapkan oleh pusat berkaitan dengan dengan demokrasi dan otonomi daerah ini. Akibatnya pelaksanaan demokrasi dan otonomi daerah dianggap telah menjadi masalah baru dalam penyelenggaraan negara di Indonesia (Lihat Bertrand 2004:202-203).

Dilihat secara kelembagaan, muncul pula persaingan kuasa antara eksekutif dan legislatif daerah. Keadaan ini menyebabkan hubungan politik antara eksekutif dan legislatif menjadi tidak harmonis (Wasistiono 2005:176-177). Berdasarkan UU No. 22 tahun 1999 Pasal 46 ayat (3) dinyatakan adanya kekuasaan legislatif daerah yaitu Dewan Perwakilan Rakyat Daerah (DPRD) untuk memberhentikan kepala daerah (gubernur, bupati/walikota) apabila laporan pertanggungjawaban di setiap akhir tahun anggaran ditolak DPRD. Besarnya kekuasaan DPRD ini juga terlihat di Pasal 49 ayat ( $g$ ) di mana DPRD bisa memberhentikan kepala daerah apabila pelaksanaan tugas-tugasnya didapati menyebabkan krisis publik. Pemberhentian dilakukan apabila keterangan kepaia daerah tidak bisa diterima DPRD. Dalam kenyataannya, DPRD memang memiliki kekuasaan yang sangat besar sehingga kedudukan kepala daerah berasa tidak selamat, khususnya ketika akan memberikan

9. Otonomi daerah yang diharapkan menjadi paradoks ketika elite daerah dan rakyatnya mempunyai pemahaman yang berbeda terhadap pelaksanaan otonomi ini. Ini bisa dibuktikan, munculnya egosentrisme kedaerahan yang berlebihan sehingga tidak memberi tempat bagi pendatang untuk bekerja di daerah itu. Elite politik pun merasa besar di daerahnya dan-menguatkan kekuasaanya atas rakyat. Kuasa elite daerah pun kerap disalahgunakan terutama dalam menunjuk orang-orang untuk duduk di birokrasi daerah yang hanya berdasarkan kronisme dan kekeluargaan (lihat selanjutnya Pratikno 2005:61; Asrinaldi et al 2005:21-30). 
laporan pertanggungjawaban tahunan di hadapan DPRD. ${ }^{10}$

Hingga UU No. 22 tahun 1999 diimplementasikan 1 Januari 2001 temyata belum ada kemajuan yang berarti berkaitan dengan pelaksanaan demokrasi di daerah. Sebaliknya, apa yang muncul ialah perilaku yang jauh dari kesan demokratis seperti menguatnya gaya kepimpinan otoritarian di daerah, muncul pula chauvinisme kedaerahan, etnosentrisme dalam berotonomi bahkan praktik kekuasaan feudalisme muncul kembali di daerah. ${ }^{1 "}$ Mengkhawatirkan realitas ini, pemerintah pusat mengambil kebijakan politik dengan merevisi kembali isi dan pelaksanaan UU No. 22 tahun 1999 yang sudah dipraktikkan lebih kurang lima tahun. Pemerintah pusat berkeyakinan bahwa ia mesti mengambil suatu keputusan politik yang bermakna untuk mengubah UU No. 22 tahun 1999 tersebut sehingga agenda demokrasi tidak terganggu. Melalui kajian dan perbincangan dengan Dewan Perwakilan Rakyat (DPR), akhirnya pemerintah pusat menggantikan UU No. 22 tahun 1999 dengan UU No. 32 tahun 2004. Jelas, bahwa tujuan mengganti UU ini adalah untuk membina kembali implementasi otonomi daerah yang tidak sesuai dengan harapan pusat bagi kehidupan yang lebih harmonis dan demokratis, di mana kerapkali terjadi perselisihan dalam pelaksanaannya, baik antara pemerintah daerah maupun rakyatnya.

Diterbitkannya UU No. 32 tahun 2004 ini, oleh sebagian pihak dianggap mengekalkan kembali kekuasaan pusat untuk campur tangan dalam pelaksanaan demokrasi di tingkat lokal. Sebab, apabila UU ini diberlakukan, maka pemerintah pusat memiliki legitimasi secara konstitusi mengendalikan daerah dalam berotonomi. ini dianggap sebagai langkah politik pusat guna mengekalkan kekuasaannya kembali atas daerah terutama dalam pelaksanaan otonomi daerah. Pusat berpandangan bahwa apabila perannya mengendalikan otonomi daerah tersebut diperkuat kembali, maka demokrasi di tingkat lokal akan lebih mudah dibentuk sesuai dengan keinginannya.

Penguatan peranan negara kuat adalah pilihan yang mesti dibuat oleh pemerintah untuk mencegah munculnya ancaman disintegrasi bangsa melalui pelaksanaan otonomi daerah. Oleh itu, pemerintah pu-

10. Besarnya kewenangan DPRD yang diberikan oleh UU No. 22 tahun 1999 berdampak pada lahirnya penyalahgunaàn kekuasaan oleh DPRD. Misalnya dalam pelaksanaan pemberian laporan pertanggungjawaban (progress report) tahunan kepala daerah. Kedudukan kepala daerah bisa terancam oleh kekuasaan DPRD yang bisa menolak laporan pertang-gungjawaban ini. Untuk kelancaran penyam-paian laporan pertanggungjawaban ini berlaku tawar menawar di mana kepala dáerah meminta késediaan DPRD menerima. laporan pertanggungjawabannya dengan janji adanya pemberian "fasilitas" atau "uang" kepada setiap anggota DPRD dengan cara menaikan gaji dan tunjangan lain (misalnya dana purnabakti) bagi anggota DPRD dalam APBD. Lihat Bali Online 26 Juli 2004. www.balipost.co.id diakses tanggal 2 Maret 2006.

11. Bukti adanya praktik feudalisme tersebut adalah.di mana kepala daerah dan stafnya di pemerintahan memiliki kekuasaan yang besar atas rakyat untuk menentukan program kerja pemerintah tanpa mendengarkan keinginan rakyat. Keterlibatan rakyat dalam mengendalikan kekuasaan sangat terbatas. Kenyataannya pemerintah daerah tidak berkhidmat pada rakyat, sebaliknya rakyatlah yang mesti berkhidmat pada elite pemerintah daerah. Ini dapat dilihat, untuk peningkatan pendapatan asli daerah guna pembiayaan program-program pemerintahan, kerap kali di banyak tempat kepala daerah dan DPRD menerbitkan Peraturan Daerah (Perda) guna menarik sejumlah uang dalam bentuk pajak atau retribusi kepada rakyatnya. 
sat menguatkan kekuasaannya dengan membina kembali kekuatannya sebagai usaha mengawal demokrasi di tingkat lokal melalui implementasi otonomi daerah. Gejala ini memiliki kesamaan dengan pemerintah Orde Baru ketika menerapan model autonomi nyata dan bertanggung jawab yang melihat bahwa otonomi daerah mesti dipandang sebagai masalah politik ketimbang sebagai masalah teknik administrasi pemerintahan di tingkat lokal. ${ }^{12}$

Pemerintah pusat menganggap desentralisasi bukanlah ubat mujarab mengatasi semua masalah di daerah. Karenanya, otonomi daerah sangat bergantung pula kepada kondisi di mana otonomi itu berlaku. Implementasi otonomi daerah harus boleh melahirkan campur tangan. Untuk campur tangan itu negara harus kuat. Negara boleh mengatur dan memaksakan kehendaknya pada rakyat sesuai dengan fungsinya termasuk memaksakan apa yang terbaik untuk daerah dalam melaksanaan autonomi. Sebab jika tidak, kewujudan NKRI tidak lagi ditemukan dalam kehidupan antar bangsa. Selama ini sudah bisa dibuktikan banyaknya kasus otonomi daerah yang diselenggarakan dengan menggunakan UU No. 22/1999 ialah bukti lemahnya negara. Negara yang lemah yaitu yang tidak mampu menjaga autoritinya, boleh mendatangkan pelbagai persoalan (Fukuyama 2005:xvii-xxii).

Oleh karena itu, dengan politik kekuasaannya pemerintah berusaha kembali menguatkan peranan negara. Berkaitan dengan politik kekuasaan ini, Wright (1978:23) menjelaskan bahawa dimensi yang terkait dengan politik kekuasaan negara itu ialah adanya kebebasan unit-unit politik yang mengakui tidak ada superioritas dan klaim kedaulatan, kecuali negara. Selain itu hubungan antara unit-unit politik yang ada harus tetap dan terkendali. Pemahaman terhadap dimensi politik kekuasaan ini menyebabkan pemerintah pusat berperan penuh dalam mengendalikan transisi demokrasi yang berlangsung di tingkat nasional. ataupun lokal.Transisi demokrasi melalui pelaksanaan otonomi daerah yang seluasluasnya boleh diwujudkan, namun tetap harus dikendalikan oleh pusat. Peran negara seperti ini perlu dilakukan mengingat realitas bangsa Indonesesia yang plural boleh menjadi salah satu faktor terciptanya konflik yang mengancam kesatuan berbangsa dan bernegara.

\section{Penutup}

Keberadaan negara tidak mungkin dinafikan dalam kehidupan berbangsa dan

12. Implementasi otonomi daerah masa Orde Baru berbeda dengan masa Orde Reformasi yaitu: (i) dari aspek UU yang mengatur bahwa otonomi daerah pada masa Orde Baru dilaksanakan dengan berasaskan pada UU No. 5./1974. Sementara, otonomi daerah pada masa Orde Reformasi ialah UU No. 22/1999 dan direvisi dengan UU No. 32/2004; (ii) prinsip otonomi UU No. 5/1974 ialah otonomi nyata dan bertanggung jawab yaitu suatu kuasa pemerintah daerah melaksanakan tugas sesuai dengan kemampuannya.Bertanggung jawab adalah pelaksanaan kuasa otonomi itu pemerintah daerah mesti sesuai dengan tujuan yang ditetapkan. Apabila pemerintah pusat menganggap bahawa pemerintah daerah tidak mampu melaksanakan otoritasnya, pusat boleh menarik kembali kewenangan yang diberikan kepada daerah tersebut. Sementara UU No. 32/2004 ialah otonomi seluas-luasnya yaitu daerah diberi kekuasaan mengurus dan mengatur semua urusan pemerintahan di luar yang menjadi urusan pemerintah pusat yang diatur oleh UU ini. Dalam penjelasan UU No. 32/2004 bahwa pelaksanaan otonomi daerah yang seluas- luasnya mesti selaras pula dengan pelaksanaan prinsip lain yaitu otonomi nyata dan bertanggung jawab. 
bernegara. Negara diperlukanjika ingin tetap mewujudkan harmonisasi kehidupan rakyat. Perwujudan kontrak sosial yang dilembagakan dengan kehadiran negara membawa implikasi pada kerelaan individuindividu warga negara untuk diatur oleh negara. Dengan kata lain, negara berdaulat atas kekuasaannya dihadapan rakyatnya. Namun persoalannya, siapa yang dapat menjamin bahwa kekuasaan negara digunakan untuk kepentingan rakyatnya. Dalam kondisi transisi ke demokrasi, memang diperlukan negara kuat. Apalagi dalam kondisi masyarakat Indonesia yang plural. Transisi demokrasi yang sedang berlangsung melalui pelaksanaan otonomi daerah saat ini sudah memberi gambaran bagaimana demokrasi tersebut dipahami oleh rakyat Indonesia. Paling tidak ketika UU No. 22 tahun 1999 dilaksanakan negara pada kondisi pasif (lemah), akibatnya terjadi konflik di banyak daerah. Dapat disimpulkan bahwa berlakunya UU No. 32 tahun 2004 menggantikan UU No. 22 tahun 1999 ialah bukti nyata keinginan pusat untuk kembali mengendalikan daerah melalui penguatan peranan negara dalam proses demokrasi di tingkat lokal. Namun apakah kondisi ini juga memberi kemanfaatan bagi penguatan rakyat dalam berpolitik dan berpemerintahan di tingkat lokal? Mari kita lihat.

\section{Daftar Pustaka}

Agung, Ide AnakAgung Gde, 1983. Renville. Jakarta: Sinar Harapan.

Asrinaldi, Yoserizal, Aidinil Zetra, Yopi Fetrian, Roni Ekha Putera, 2005. "Optimalisasi pembinaan dan pemanfaatan aparatur antar daerah kabupaten/kota dan provinsi di Sumatera Barat." Laporan Penelitian Lembaga Penelitian Universitas Andalas dengan kerjasama Balibangda Provinsi Sumatera Barat.

Bertrand, Jacques. 2004. Nationalism and Ethnic Conflict in Indonesia. Cambridge: Cambridge University Press.

Clark, Simon. (Pnyt.). 1991. The State Debate. London: Macmillan

Cribb, Robert. 1999. Nation: Making Indonesia. Dalam Donald K. Emerson (penyt). Indonesia Beyond Soeharto: polity, economy, society, transition. New York: An East Gate Book. Hal. 3-38.

Davidson, Jamie. E. 2005. Decentralization and regional violence in the post Suharto State. Dalam Maribeth Erb, Priyambudi Sulistiyanto, CarolenFaucher (Pnyt.), Regionalism Post-Suharto Indonesia. London: RoutledgeCurzon. Hal. 170-190.

Dieckhoff, Alain. 2003. Nationalism. Dalam Dalam Roland Axtmann (ed). 2003. Understanding Democratic Politics. Hal. 271-279. London: Sage Publications.

Feith, Herbert \& Castles, Lance. 1970. Introduction. Dalam Herbert Feith \& Lance Castles (Pnyt.). Indonesian political thinking. Hal.1-24. Ithaca: Cornell University Press.

Fukuyama, Francis, 2005. Memperkuat Negara: tata pemerintahan dan tata dunia abad 21. Jakarta: Gramedia.

Gaffar, Afan. 1999. Politik Indonesia: transisi menuju demokrasi. Yogyakarta: Pustaka Pelajar. 
Jackson, Karl D. 1978. Bureaucratic polity: a theoritical framework for the analysis of power and communications in Indonesia. Dalam Karl D Jackson \& Lucian W. Pye (Pnyt.). Political power and communications in Indonesia. Berkeley: University of California Press.

Kahin, Audrey. 2005. Dari Pemberontakan Ke Integrasi: Sumatera Barat dan politik Indonesia 1926-1998. Jakarta: Yayasan Obor Indonesia.

Kieden, Ignas. 2003. Indonesia setelah lima tahun reformasi. Analisis CSIS. Tahun 32(2):160-172.

Legge, J.D. 1961. Central authority and regional authonomy in Indonesia: a study in local administration 19501960. Ithaca: Cornell University Press.

Liddle, R. William, 1999. Regime: The new order. Dalam Donald K. Emerson (penyt). "Indonesia Beyond Soeharto: Polity, economy, society, transition". New York: An East Gate Book. Hal. 39-70.

Linz, Juan. J \& Stepan, A. 1996. Problems of Democratic Transition and Consolidation: Southern Europe, South America and post-comunist Europe. Baltimore: Johñs Hopkins University Press.

MacAndrew, Colin. 1986. Central government and local development in Indonesia: An overview. Dalam MacAndrew, Colin. (penyt). Central Government and Local Development in Indonesia. Hal.6-19. Oxford: Oxford University Press.
Malley, Michael. 1999. Regions: centralization and resistence. Dalam Donald K. Emerson (penyt). Indonesia Beyond Soeharto: polity, economy, society, transition. New York: An East Gate Book. Hal. 71-105.

Miliband, Ralph. 1969. . The State in Capitalist Society. London: Weidenfeld \& Nicolson.

McVey, Ruth. 2003. Nation versus state in Indonesia. Dalam Damien Kingsbury dan Harry Aveling (penyt). Autonomy and Disintegration in Indonesia. London: RoutledgeCurzon. Hal. 11-27.

Pratikno, 2005. Iniating Participatory Democracy in Indonesia: The Case of Surakarta Municipality. Dalam Asia Pacific Perspectif an Electronic Journal. 5(2):59-66. University of San Fransisco Center for the Pacific Rim. http//www.pacificrim.usfca.edu/research/perspectives Akses 5 Januari 2006.

Rasyid Ryaas, Muhammad. 1994. The state formation, party system, and the prospect for democracy in Indonesia: the case of Golkar (1967-1993). Disertasi Ph.D, University of Hawaii.

Rondinelli, Dennis A \& Cheema, G. Shabbir. 1983. implementing decentralization policies: an introduction. Dalam G. Shabbir Cheema and Dennis A. Rondinelli (Pnyt). Decentralization And Development: policy implementation in developing countries. Hal.934. London: Sage Publication.

Smith, B.C. 1985 . Decentralization: the teritorial dimension of state. London: George Allen \& Unwin. 
Penguatan Peran Negara dalam Implementasi Demokrasi Lokal...: Asrinaldi A

Wasistiono, Sadu. 2005. Desentralisasi dan otonomi daerah masa reformasi (1999-2004). Dalam Anonimous. Pasang Surut Otonomi Daerah: Sketsa perjalanan 100 tahun. Hal. 155-196. Jakarta: Yayasan TIFA.
Wright, Martin. 1978, Power Politics. New York: Holmes \& Meier Publisher.

$\square \square \square$ 